\title{
Suprageneric nomenclature in the Caryophyllaceae
}

\author{
Richard K. Rabeler ${ }^{1}$ \& Volker Bittrich ${ }^{2}$
}

\begin{abstract}
Summary
Rabeler, R. K. \& Bittrich, V.: Suprageneric nomenclature in the Caryophyllaceae. - Taxon 42: 857-863. 1993. - ISSN 0040-0262.
\end{abstract}

All known suprageneric names within the Caryophyllaceae are listed.

Through our work on the nomenclature of the Caryophyllaceae in preparing our treatments for the Generic flora of the southeastern United States (Rabeler, in prep.) and for The families and genera of the vascular plants (Bittrich, in prep.) we uncovered a number of problems involving the suprageneric names being used in the Caryophyllaceae. Given the increased interest in higher-level relationships in the Caryophyllidae that has arisen from the application of molecular (e.g., Giannasi \& al., 1992) and cladistic methods (e.g., Rodman \& al., 1984; Rodman, 1990; Hershkovitz, 1991) and from questions about relationships within the Caryophyllaceae (e.g., Gilbert, 1987; Hershkovitz, 1991), we feel that it is appropriate to present an overview of validly published suprageneric names.

\section{Names of subdivisions and segregates of the Caryophyllaceae}

We follow the format of Nicolson (1984) and Sanders \& Cantino (1984), listing the available names (known to us) under the generic name providing their type. We likewise follow Nicolson (1984) in extending Art. 18.2 of the current Code (Greuter \& al., 1988) to allow substitution of "subfamily" for "subordo", an extension that has just been approved by the XV International Botanical Congress (McNeill, 1993). Authorship for two commonly used subfamily names was changed under this convention. Use of parenthetical authors follows Nicolson (1984). Two other provisions of the Code were invoked frequently during the construction of this compilation, namely Art. 19.6 (allowing correction of incorrect terminations) and the combination of Art. 19.1-3 and 32.1(b) (names with the prefix with $E u$ - are invalidly published).

We follow Art. 19.3 of the Code, as recently amended (McNeill, 1993), in forming obligatory names (formerly: autonyms) for names of family subdivisions that include the type of the family name, Caryophyllus Miller ( $\equiv$ Dianthus L.). These had never been formally validated to the best of our knowledge, and are validated here by reference to the Latin description validating the family name Caryophyllaceae (see Art. 41.1 as modified by the XV IBC). The proposal to amend Art. 18.3 to allow use of "autonyms" subordinate to a conserved family name (Gilbert \& Bittrich, 1991) having been accepted, names based on Dianthus in these ranks, as used by Sourková (1978), are now invalid. These names are nevertheless included in our listing, along with other names not so far validly published, for all of which square brackets are used.

\footnotetext{
${ }^{1}$ The University of Michigan Herbarium, North University Building, Ann Arbor, MI 48109-1057, U.S.A.

${ }^{2}$ Departamento de Botânica, Instituto Nacional de Pesquisas da Amazônica, Al Cosme Ferreira, Caixa Postal 478, 69083 Manaus, Amazonas, Brazil.
} 
Unranked names (Art. 35) are given in those cases in which a reference to them has served to validate later names in definite ranks (as shown by parenthetical author citation).

Acanthophyllum C. Mey.

Subtribe Acanthophyllinae Sourk. in Preslia 50: 150. 1978.

Alsine L.

Fam. Alsinaceae (DC.) Bartl. in Bartling \& Wendland, Beitr. Bot. 2: 159. 1825, 'Alsineae', nom. cons.

Subfam. Alsinoideae Fenzl in Endlicher, Gen. Pl.: 963. 1840, 'subordo Alsineae'.

Tribe Alsineae (DC.) Ser. in Candolle, Prodr. 1: 388. 1824.

[Unranked] Alsineae DC. in Lamarck \& Candolle, Fl. France, ed. 3, 4(2): 766.1815.

Alsinidendron $\mathrm{H}$. Mann

[Tribe Alsinidendreae Rohw. in Bot. Jahrb. Syst. 90: 202. 1970, 'Alsinodendreae', nom. nud.]

\section{Arenaria L.}

Tribe Arenarieae Rohrb. in Martius, Fl. Brasil 14(2): 262. 1872.

Subtribe Arenariinae Dumort., Fl. Belg.: 109. 1827, 'Arenarieae'.

Caryophyllus Mill., non L. (三Dianthus)

Fam. Caryophyllaceae Juss., Gen. Pl.: 299. 1789, nom. cons.

Subfam. Caryophylloideae (Juss.) Rabeler \& Bittrich, stat. nov.

Tribe Caryophylleae (Juss.) Rabeler \& Bittrich, stat. nov.

Subtribe Caryophyllinae (Juss.) Rabeler \& Bittrich, stat. nov.

Cerastium L.

Subfam. Cerastioideae Hayek, Fl. Steiermark 1: 270. 1908.

Subtribe Cerastiinae Dumort., Fl. Belg.: 108. 1827, 'Cerastieae'.

Cometes L.

Tribe Cometeae Meisn., Pl. Vasc. Gen. 1: 133; 2: 97.1838.

Corrigiola L.

Fam. Corrigiolaceae (Dumort.) Dumort., Anal. Fam. Pl.: 49. 1829.

Tribe Corrigioleae Dumort., Fl. Belg.: 86. 1827.

Subtribe Corrigiolinae Fenzl in Endlicher, Gen. Pl.: 956. 1839, 'Corrigioleae'.

Cucubalus L.

[Subfam. Cucubaloideae Leonhardt in Österr. Bot. Z. 98: 12. 1951, nom. nud.]

Subtribe Cucubalinae Pax in Bot. Jahrb. Syst. 61: 232. 1927.

Dianthus L.

[Fam. Dianthaceae Drude in Schenk, Handb. Bot. 3(2): 395. 1886, nom inval. (Art. 18.3, 19.3 and 32.1(b))].

[Subfam. Dianthoideae Sourk. in Preslia 50: 148. 1978, nom inval. (Art. 18.3, 19.3 and 32.1(b))].

[Tribe Diantheae Dumort. Anal. Fam. Pl.: 49.1829, nom inval. (Art. 18.3, 19.3 and 32.1(b))].

[Subtribe Dianthinae Sourk. in Preslia 50: 148. 1978, nom inval. (Art. 18.3, 19.3 and 32.1(b))] 
Drymaria Willd. ex Schult.

[Tribe Drymarieae F. Williams in J. Linn. Soc., Bot. 32: 22. 1896, nom. nud.]

[Unranked Drymarieae Small, Man. S.E. Fl.: 496. 1933, nom. nud.]

Drypis L.

[Subfam. Drypidoideae Leonhardt in Österr. Bot. Z. 98: 12. 1951, nom. nud.]

Tribe Drypideae Fenzl in Endlicher, Gen. P1.: 974. 1840.

Subtribe Drypidinae Pax in Bot. Jahrb. Syst. 61: 232. 1927.

Geocarpon Mackenzie

Tribe Geocarpeae E. J. Palmer \& Steyerm. in Bull. Torrey Bot. Club 77: 272. 1950.

Gypsophila L.

Subtribe Gypsophilinae Sourk. in Preslia 50: 149.1978.

Habrosia Fenzl

[Subfam. Habrosioideae Leonhardt in Österr. Bot. Z. 98: 4. 1951, nom. nud.]

Tribe Habrosieae Pax in Bot. Jahrb. Syst. 61: 231. 1927.

Subtribe Habrosiinae Fenzl in Bot. Zeitung (Berlin) 1843: 326. 1843, 'Habrosieae'.

Herniaria L.

Subfam. Herniarioideae Rouy, Fl. France 12: 2. 1910, 'Herniarineae'.

Honckenya Ehrh.

Tribe Honckenyeae Kozh. in Budancev, Vopr. Sravnit. Morf. Semen. Rast.: 124. 1975.

Illecebrum L.

Fam. Illecebraceae R. Br., Prodr.: 413. 1810, 'Illecebreae', nom. cons.

Subfam. Illecebroideae (R. Br.) Rossb. in Martius, Fl. Brasil. 14(2): 247. 1872, 'Illecebreae'.

Tribe Illecebreae DC., Prodr. 3: 367. 1828.

Subtribe Illecebrinae (R. Br.) Graebn. in Ascherson \& Graebner, Syn. Mitteleur. Fl. 5(1): 870. 1919.

Loeflingia $\mathrm{L}$.

Subtribe Loeflingiinae Fenzl in Endlicher, Gen. Pl.: 960. 1839, 'Loeflingieae'.

Lychnis L.

Tribe Lychnideae Fenzl in Endlicher, Gen. Pl.: 971.1840.

[Subtribe Lychnidinae Janchen in Österr. Bot. Z. 102: 386. 1955, nom. nud.; Cat. Fl. Austriae: 143. 1956, nom. nud.]

Malachium Fr. ex Reichb. 1832, nom. illeg. (三 Myosoton Moench 1794)

[Subtribe Malachiinae Fenzl in Endlicher, Gen. Pl.: 970. 1840, 'Malachieae', nom. inval. (Art. 19.1-3 and 32.1(b))]

Merckia Fischer ex Cham. \& Schldl. 1826, non Merkia Borkh. 1792 (三Wilhelmsia Reichb.)

[Tribe Merckieae Fenzl in Endlicher, Gen. Pl.: 966. 1840, nom. inval. (Art. 18.1 and 32.1(b))].

Minuartia L.

Tribe Minuartieae DC., Prodr. 3: 379. 1828, 'Minuartiae'. 


\section{Ortegia L.}

[Tribe Ortegieae Baptista, Discuss. Carac. Distinct. Fam. Paronych.: 12. 1855, 'Ortegias', nom. inval. (Art. 18 Ex. 6, 19.6 and 32.1(b))].

\section{Paronychia Hill}

Fam. Paronychiaceae Juss. in Mém. Mus. Hist. Nat. 2: 386. 1816, 'Paronychieae'. Subfam. Paronychioideae Meisn., P1. Vasc. Gen. 1: 132; 2: 96.1838 , 'subordo Paronychieae'.

Tribe Paronychieae Dumort., Fl. Belg.: 86. 1827.

Subtribe Paronychiinae Pax in Bot. Jahrb. Syst. 61: 231. 1927.

Plettkea Mattf.

[Tribe Plettkeeae Leonhardt in Österr. Bot. Z. 98: 5. 1951, 'Plettkeae', nom. nud.]

Subtribe Plettkeinae Mattf. in Engler \& Prantl, Nat. Pflanzenfam., ed. 2, 16c: 367. 1934.

\section{Pollichia Aiton}

Tribe Pollichieae DC., Prodr. 3: 377. 1828.

Subtribe Pollichiinae Pax in Bot. Jahrb. Syst. 61: 231. 1927.

Polycarpaea Lam.

Subfam. Polycarpoideae Tanf. in Parlatore, Fl. Ital. 9: 623. 1892, 'Polycarpineae'. Tribe Polycarpeae DC., Prodr. 3: 373. 1828.

Pteranthus Forssk.

Subfam. Pteranthoideae Luders in Bot. Jahrb Syst. 40, Beibl. 91: 29. 1907.

Tribe Pterantheae R. Br. ex Fenzl in Endlicher, Gen. Pl.: 959. 1839.

Pycnophyllum Skottsb.

Tribe Pycnophylleae Mattf. in Repert. Spec. Nov. Regni Veg. 18: 167. 1922.

\section{Queria L. (= Minuartia L.)}

Tribe Querieae DC., Prodr. 3: 379. 1828. 'Queriaceae'

Sabulina Rchb. (= Minuartia L.)

Tribe Sabulineae Fenzl in Endlicher, Gen. Pl.: 963. 1840.

Subtribe Sabulininae (Fenzl) Graebn. in Ascherson \& Graebner, Syn. Mitteleur. Fl. 5(1): 448. 1915.

\section{Sagina L.}

Tribe Sagineae Caruel in Parlatore, Fl. Ital. 9: 564. 1892.

Subtribe Sagininae Fenzl in Endlicher, Gen. Pl.: 963. 1840, 'Sagineae’.

\section{Saponaria L.}

Tribe Saponarieae Neum. in Verh. Zool.-Bot. Ges. Wien 72: 53. 1921.

[Subtribe Saponariinae Janchen in Österr. Bot. Z. 102: 385. 1955, nom. nud.; Cat. Fl. Austriae: 143. 1956, nom. nud.]

Schischkiniella Steenis

Subtribe Schischkiniellinae Ikonn. in Novosti Sist. Vyš̌ Rast. 14: 75. 1977.

\section{Scleranthus L.}

Fam. Scleranthaceae (A. St.-Hil.) Bartl. in Bartling \& Wendland, Beitr. Bot. 2: 153. 1825, 'Sclerantheae'. 
Subfam. Scleranthoideae Meisn., Pl. Vasc. Gen. 1: 133; 2: 97.1838 , 'subordo Sclerantheae'.

Tribe Sclerantheae DC., Prodr. 3: 377. 1828.

Subtribe Scleranthinae Mattf. in Engler \& Prantl, Nat. Pflanzenfam., ed. 2, 16c: 367. 1934.

[Unranked] Sclerantheae A. St.-Hil. in Bull. Sci. Soc. Philom. Paris 1815: 38. 1815.

Silene L.

Fam. Silenaceae (Ser.) Bartl. in Bartling \& Wendland, Beitr. Bot. 2: 160. 1825, 'Sileneae'.

Subfam. Silenoideae Fenzl in Endlicher, Gen. P1.: 970. 1840, 'subordo Sileneae'.

Tribe Sileneae DC. ex Ser. in Candolle, Prodr. 1: 351. 1824.

Subtribe Sileninae F. Williams in J. Linn. Soc., Bot. 32: 4. 1896, 'Silenoideae'.

Spergula L.

Tribe Sperguleae Dumort. in Anal. Fam. Pl.: 49. 1829.

Subtribe Spergulinae Dumort., Fl. Belg.: 110. 1827, 'Sperguleae'.

Spergularia (Pers.) J. Presl \& C. Presl.

Tribe Spergularieae Willk. in Willkomm \& Lange, Prodr. Fl. Hispan. 3: 161. 1874.

Sphaerocoma T. Anderson

Tribe Sphaerocomeae Boiss., Fl. Orient. 1: 738. 1867.

Stellaria L.

Fam. Stellariaceae Dumort., Fl. Belg.: 106. 1827.

Tribe Stellarieae Fenzl in Endlicher, Gen. P1.: 966. 1840, 'Stellarineae'.

Subtribe Stellariinae (Fenzl) Graebn. in Ascherson \& Graebner, Syn. Mitteleur. Fl. 5(1): 448. 1915.

Telephium L.

Fam. Telephiaceae Link, Handb. 2: 45.1831.

Subfam. Telephioideae Tanf. in Parlatore, Fl. Ital. 9: 629. 1893, 'Telephineae'.

Tribe Telephieae DC., Prodr. 3: 366. 1828.

Subtribe Telephiinae (Bartl.) Graebn. in Ascherson \& Graebner, Syn. Mitteleur. Fl. 5(1): 854. 1919.

[Unranked] Telephieae Bartl. in Bartling \& Wendland, Beitr. Bot. 2: 158. 1825.

Xerotia Oliver

Tribe Xerotieae Pax in Bot. Jahrb. Syst. 61: 231. 1927.

Pax \& Hoffmann's subdivisions of the Caryophyllaceae and their correct names

The treatment of the Caryophyllaceae by Pax \& Hoffmann (1934), modified slightly by Mattfeld (1934), remains the most widely used classification scheme, although many of their tribe and subtribe names are rarely used in recent literature. Leonhardt $(1951)$ and Janchen $(1955,1956)$ proposed revised schemes, but both include several names that are not validly published. Table 1 illustrates the schemes of Pax \& Hoffmann (1934) and the Mattfeld (1934) modifications (entries in curly brackets), both as published and as correct under the current rules. We wish to emphasize that this is given as an example; as Hershkovitz (1991) implies, future work may significantly modify the relationships that Pax \& Hoffmann postulated. 
Table 1. Names of taxa accepted in the classification of Pax \& Hoffmann (1934), both as accepted there (left) and as currently correct (right). Names in curly brackets are either additional, or meant to replace the name immediately preceding them, in Mattfeld's Nachtrag to Pax \& Hoffmann. An asterisk $\left(^{*}\right)$ indicates names that are incorrect or invalid.

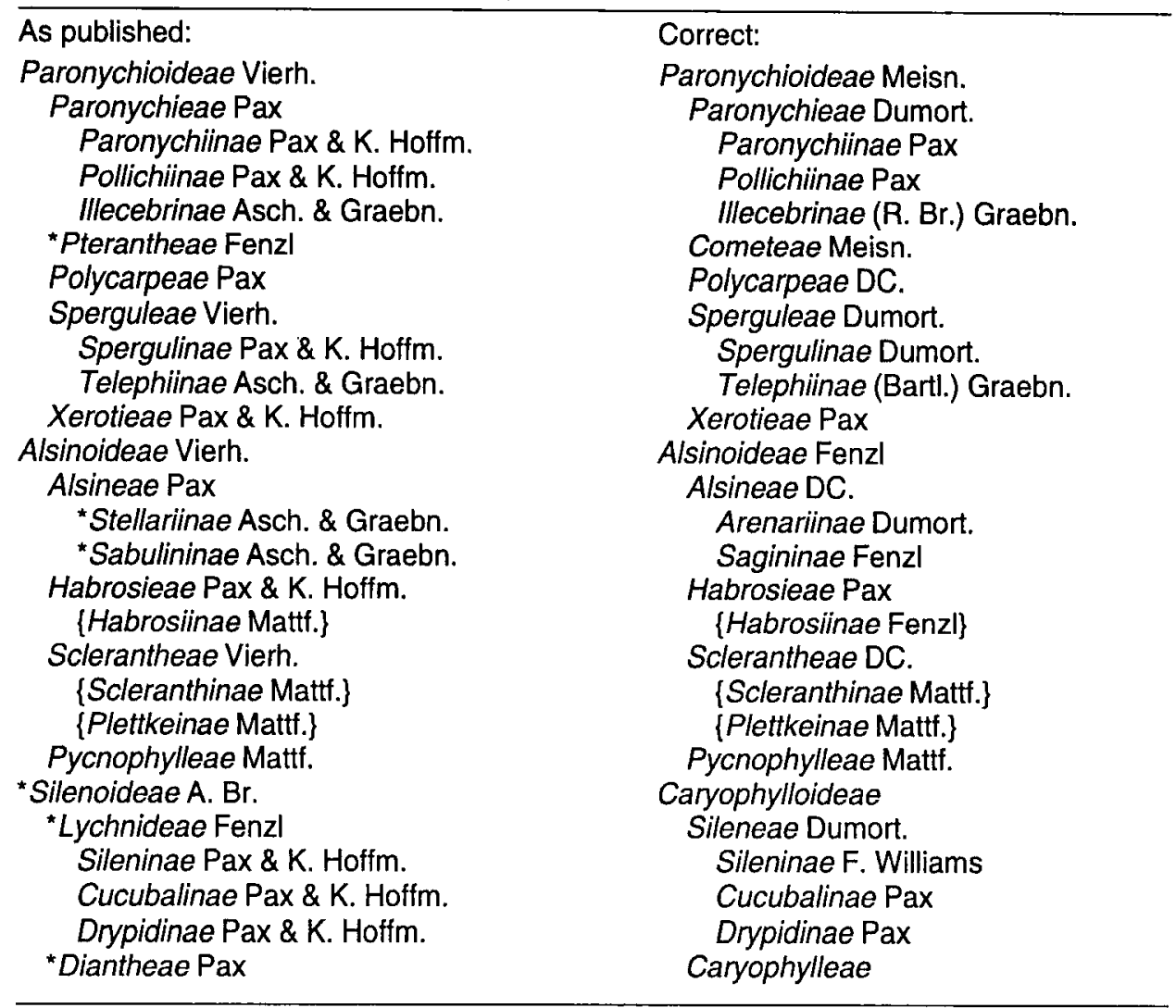

Acknowledgements

We thank A. A. Reznicek and E. G. Voss for nomenclatural advice, and library personnel at GH, MICH, MO, NY, US, and the Library of Congress, Washington, $\mathrm{DC}$, for assistance in accessing critical literature.

\section{Literature cited}

Giannasi, D. E., Zurawski, G., Learn, G. \& Clegg, M. T. 1992. Evolutionary relationships of the Caryophyllidae based on comparative rbcL sequences. Syst. Bot. 17: 1-15.

Gilbert, M. G. 1987. The taxonomic position of the genera Telephium and Corrigiola. Taxon 36: 47-49.

- \& Bittrich, V. 1991. (55) Proposal to amend Art. 18.3. Taxon 40: 686.

Greuter, W., Burdet, H. M., Chaloner, W. G., Demoulin, V., Grolle, R., Hawksworth, D. L., Nicolson, D. H., Silva, P. C., Stafleu, F. A., Voss, E. G. \& McNeill, J. (ed.), 1988. International code of botanical nomenclature, adopted by the Fourteenth International Botanical Congress, Berlin, July-August 1987. Regnum Veg. 118.

Hershkovitz, M. A. 1991. More Centrospermae III: The caryophyllaceous alliance, Aizoaceae, odd taxa, and summary. Amer. J. Bot. 78 (suppl. to 6): 192. (abstract). 
Janchen, E. 1955. Naturgemässe Anordnung der mitteleuropäischen Gattungen der Silenoideae. Österr. Bot. Z. 102: 381-386.

- 1956. Catalogus florae austriae, 1(1). Vienna.

Leonhardt, R. 1951. Phylogenetisch-systematische Betrachtungen. II. Gedanken zur systematischen Stellung, bzw. Gliederung einiger Familien der Choripetalen. I. (Caryophyllaceen.) Österr. Bot. Z. 98: 2-12.

Mattfeld, J. 1934. Nachtrag zu den Caryophyllaceae. Pp. 365-367 in: Engler, A. \& Harms, H. (ed.), Die näturlichen Pflanzenfamilien, ed. 2, 16c. Leipzig.

McNeill, J. 1993. XV International Botanical Congress: preliminary mail vote and report of Congress action on nomenclatural proposals. Taxon 42: 907-922.

Nicolson, D. H. 1984. Suprageneric names attributable to Araceae. Taxon 33: 680-690.

Pax, F. \& Hoffmann, K. 1934. Caryophyllaceae. Pp. 275-364 in: Engler, A. \& Harms, H. (ed.), Die näturlichen Pflanzenfamilien, ed. 2, 16c. Leipzig.

Reveal, J. L. 1993. A splitter's guide to the higher taxa of the flowering plants (Magnoliophyta) generally arranged to follow the sequence proposed by Thorne (1992) with certain modifications. Phytologia 74: 203-263.

Rodman, J. E. 1990. Centrospermae revisited, part 1. Taxon 39: 383-393.

- Oliver, M. K., Nakamura, R. R., McClammer, J. U. \& Bledsoe, A. H. 1984. A taxonomic analysis and revised classification of Centrospermae. Syst. Bot. 9: 297-323.

Sanders, R. W. \& Cantino, P. D. 1984. Nomenclature of the subdivisions of the Lamiaceae. Taxon 33: 64-72.

Sourková, M. 1978. Caryophyllaceae subfam. Dianthoideae - Begrenzung, Charakteristik, und Gliederung. Preslia 50: 139-152.

Postscript: Shortly after work on this paper was completed, Reveal (1993: 207) made reference to nine caryophyllid family names not seen by us or with information differing from ours: Cerastiaceae Vest 1818, Dianthaceae Vest 1818, Herniariaceae Martinov, 1820; Ortegaceae Martinov, 1820; Paronychiaceae Juss., 1815; Saginaceae Spreng. ex Weinm., 1824; Scleranthaceae Bercht. \& J. Presl, 1820; Stellariaceae Dumort., 1822; and Telephiaceae Martinov, 1820. 